\title{
Verrucosispora sp. K2-04, Potential Xylanase Producer from Kuantan Mangrove Forest Sediment
}

\author{
Suhaila Mohd Omar, Norsyafawati Mohd Farouk, Nurfathiah Abdul Malek, and Zaima Azira Zainal Abidin \\ Department of Biotechnology, Kulliyyah of Science, International Islamic University Malaysia, Jalan Sultan Ahmad \\ Shah, Bandar Indera Mahkota, 25200 Kuantan, Pahang, Malaysia \\ Email: osuhaila@iium.edu.my
}

\begin{abstract}
Xylanase is the key enzyme that involves in the hydrolysis of xylan, the main constituent of the complex hemicellulose of the plant cell wall. In this study, forty actinomycetes that were isolated from the sediment of Kuantan Mangrove Forest, Malaysia, were tested for their ability to produce extracellular xylanase. At least 15 isolates were able to degrade xylan in the primary agar-based screening on marine agar containing $0.1 \%$ (v/v) azo-xylan (Birchwood). The degradation of xylan was indicated by the formation of halo zone around the colonies and the clear zone index (CZI) was calculated as a ratio of the clearing zones to the colony size. Isolate K2-04 with CZI $3.35 \pm 1.91$ was identified through $16 \mathrm{~S}$ rRNA study as Verrucosispora sp. This isolate was further grown in marine broth and incubated at $30{ }^{\circ} \mathrm{C}, 200 \mathrm{rpm}$ for 20 days. The growth of $\mathrm{K2}$ 04 and the xylanase activity was measured at day $2,4,6,12$ and 18 respectively. The highest enzyme activity of the crude enzyme was recorded at day $18(1.836 \mathrm{U} / \mathrm{mL})$ and exhibited stability after 20 days storage at $4^{\circ} \mathrm{C}$. This study serves as a preliminary study to characterize the properties of Verrucosispora sp. K2-04, rare actinomycete of Kuantan Mangrove Forest, Malaysia.
\end{abstract}

Index Terms - marine Actinomycetes, xylanase, mangrove, Verrucosispora

\section{INTRODUCTION}

Peninsular Malaysia has approximately 0.11 million hectares (ha) of mangroves forest [1]. In the state of Pahang alone, there is a total of 4200 ha of mangrove forests [2]. Mangrove forests usually situated in between land and sea in tropical and subtropical latitudes which encompasses zones of estuaries, blackwater, delta, creeks, lagoons, salt pans, islands, marshes and mudflats [3], [4]. Sediment microorganisms including bacteria, fungi and actinomycetes play important role in the mangrove ecosystem as they are involved in the decomposition of organic matter and are critical for the cycling of nutrients and water [5]-[8]. The presence of rare actinomycetes has been described in different mangrove habitat [9], [10].

Recent studies indicated the potential of marine Actinomycetes as producers of novel bioactive compounds, metabolites and industrial enzymes [11],

Manuscript received February 7, 2017; revised May 12, 2017
[12]. The ability of Actinomycetes of mangrove environment to withstand high salinity, extreme tides, strong winds, high temperature, muddy and anaerobic soils [3], [5], marked its potential use especially to produce industrial enzyme such as xylanase.

Xylan is one of the major components in the complex hemicellulose which can be found in the secondary cell wall with cellulose and lignin [13], [14]. Xylanases are a widespread group of enzymes involving in the production of xylose, a major carbon source for cell metabolism. Microbial xylanase is sought after due to the demand for novel enzymes in several industries such as pulp and paper industry, biofuel industry, the pharmaceutical industry, food industry and agricultural industry [15], [16]. Among the actinomycetes, streptomyces group is considered economically important since $50-55 \%$ of known antibiotics are produced by this genus [17]. In fact, studies on xylanase from actinomycetes also concentrated on streptomyces group [18]-[20]. Therefore this study is intended to screen for xylanase activities of rare actinomycetes species such as Micromonospora, Verrucosispora, and Rhodococcus [17] from Kuantan mangrove forest.

\section{MATERIALS AND METHODOLOGIES}

\section{A. Sample Collection and Isolation of Actinomycetes}

Sediment samples were collected from 7 sampling sites of Kuantan mangrove forest. Sediment samples were collected in sterile polythene bags in triplicate per site using sterile borer within an area of $100 \mathrm{~m} 2$, at a depth of 0-30 $\mathrm{cm}$. At the laboratory, the sediment samples were aseptically air-dried at room temperature for 7-10 days until the weight is constant before being ground using sterile mortar and pestle and sieved to remove large organic matters. Then the air-dried sediment samples were subjected to 2 pretreatment procedures, namely dry heat and wet heat treatment as described in [9].

As for dry heat pretreatment, $1 \mathrm{~g}$ of air-dried sediment was heated at $120^{\circ} \mathrm{C}$ in hot air oven for $60 \mathrm{~min}$. On the other hand, for wet heat pretreatment, soil suspension containing $1 \mathrm{~g}$ of dried sediment and $9 \mathrm{ml}$ of sterilized sea water was heated in a water bath at $60^{\circ} \mathrm{C}$ for $20 \mathrm{~min}$. Morphological differences among the isolates were 
observed and isolates were selected to obtain a pure culture. Further, these isolates were subcultured on different media including Starch Yeast Extract agar (SYE), inorganic salt-starch agar (ISP4), starch-casein agar (SCA), Nutrient Agar (NA) and Marine Agar (MA).

\section{B. Primary Screening for Extracellular Xylanase}

40 samples of Actinomycetes isolated from Kuantan Mangrove Forest Reserve were inoculated onto MA plates containing 0.1\% Azo-xylan (Birchwood) (v/v) to screen for extracellular xylanase activities. The plates were incubated at $30^{\circ} \mathrm{C}$ for eight days and monitored for halo formation surrounding the Actinomycetes colonies. The screening process was done in duplicate. The clear zone index (CZI) was measured by dividing the diameter of the halo zone surrounding each colony with the diameter of the colony:

$$
\mathrm{CZI}=\frac{\text { Diameter of the halo zone }(\mathrm{mm})}{\text { Diameter of the colony }(\mathrm{mm})}
$$

\section{C. $16 S$ rDNA Analysis}

Genomic DNA of isolates K2-04 was isolated using the MasterPure ${ }^{\mathrm{TM}}$ Gram Positive DNA Purification Kit (Epicentre Biotechnologies, United States of America) and subjected to 16s rDNA amplification. Bacterial 16S rRNA gene primers, Bac8F and 1492R were used and the purified PCR product was sent for sequencing at First Base Laboratory (Malaysia). The DNA sequences were analyzed in NCBI public database by using nucleotide blast (BLASTn) tool.).

\section{Inoculum Preparation and Submerged Fermentation}

Isolate $\mathrm{K} 2-04$ was grown in the $100 \mathrm{~mL}$ cottonplugged Erlenmeyer flasks containing $20 \mathrm{~mL}$ of ZOBELL's marine broth (pH7.6, HIMEDIA) and incubated at $30^{\circ} \mathrm{C}$ for 48 hours with agitation at $200 \mathrm{rpm}$. The cultures in each flask were centrifuged at $9000 \mathrm{rpm}$ for $20 \mathrm{~min}$. Then, the pellet was washed several times and finally suspended in $20 \mathrm{~mL}$ of sterile $\mathrm{KCl}(20 \mathrm{~g} / \mathrm{L})$. Twenty-one tubes of this cell suspension were prepared as inoculum for the latter submerged fermentation requirement described below.

Twenty $\mathrm{mL}$ of the inoculum was added into $500 \mathrm{~mL}$ cotton-lugged Erlenmeyer flasks containing $180 \mathrm{~mL}$ sterile marine broth. The totals of 21 flasks were incubated on an orbital shaker at $200 \mathrm{rpm}, 30^{\circ} \mathrm{C}$. During day $2,4,6,8,10,12$ and 18 of incubation, three flasks were harvested each day respectively and labeled as replicate 1,2 and 3 . The cultures were centrifuged at $9000 \mathrm{rpm}$ for $20 \mathrm{~min}$ to obtain cell-free medium that served as a crude enzyme. The crude enzyme was transferred to a new tube for determination of xylanase activity. The pellet was dried at $65^{\circ} \mathrm{C}$ for 4 days and dry weight of the pellet was determined.

\section{E. Enzyme Assay}

The crude enzyme was diluted 50X into sodium phosphate buffer (100 mM, pH 6.0) and use as crude enzyme solution for the enzyme activity assay. $500 \mu \mathrm{L}$ of crude enzyme were pre-heated to $40^{\circ} \mathrm{C}$ and added to 500 $\mu \mathrm{L}$ of substrate solution (1 \% (w/v) Azo-xylan birchwood). The solutions were mixed thoroughly with vortex stirrer and immediately incubated in a water bath $\left(40^{\circ} \mathrm{C}\right)$ for $30 \mathrm{~min} .2 .5 \mathrm{~mL}$ of ethanol $(95 \% \mathrm{v} / \mathrm{v})$ was added to terminate the reaction. The tubes were held at room temperature for $5 \mathrm{~min}$ and then centrifuge $1000 \mathrm{~g}$ for $10 \mathrm{~min}$. The supernatant solution was poured into spectrophotometer cuvette and the absorbance of blank and reaction solution was measured at $590 \mathrm{~nm}$ against water. The enzyme activities were recorded as the increase absorbance values over time. The reaction blank was prepared by adding $2.5 \mathrm{~mL}$ of $95 \%$ ethanol to $0.5 \mathrm{~mL}$ of substrate solution $(1 \% \mathrm{w} / \mathrm{v})$ and stirred vigorously for 10 seconds. The enzyme activity was determined by referring the absorbance value of the sample to a standard curve provided by the substrate supplier (Megazyme, Ireland).

\section{RESULTS \& DISCUSSIONS}

\section{A. Potential Extracellular Xylanase Producers}

Fifteen out of 40 samples of Actinomycetes isolated from Kuantan Mangrove Forest Reserve showed halo formation on azo-xylan agar after 1-week incubation at $30{ }^{\circ} \mathrm{C}$. As illustrated in Table I, isolates K2-04, K2-06, K2-11, K2-14, K3-10, K3-13, K4-08, K4-18 and K7-06 were the isolates that showed CZI more than 1.5, which indicated their potential as extracellular xylanase producer [21]. Isolate $\mathrm{K} 2-04$ had the highest $\mathrm{CZI}$ reading (3.35) followed by isolate K7-06 (3.00) and K3-13 (2.90). The growth of K2-04 was good on SYE but only sparse on ISP4, SCA, NA, and MA. K2-04 was observed as an orange-pigmented actinomycete, non-spore forming and did not produce any diffusible pigment on SYE, ISP4, SCA and NA and marine agar. Many of the members of the Micromonosporaceae produce carotenoid mycelial pigments which giving the colonies an orange to red appearance [22]. However, K2-04 did not exhibit the development of black or brown mucous mass of spores as of other Micromonospora-like colonies but have warty spore surface with increasing age.

\section{B. 165 rDNA Analysis}

Observation of the colony morphology suggested that isolate K2-04 may belong to the Micromonosporaceae family [23]. Therefore molecular identification was conducted to verify the preliminary classification. Results from 16s rDNA analysis indicated that K2-04 had highest sequence similarity to Verrucosispora gifhornensis HRI-2 (99\%). The members of genus Verrucosispora always showed morphological characteristics typical of the family Micromonosporaceae such as orange-pigmented Verrucosispora fiedleri [24], Verrucosispora maris [25], Verrucosispora wenchangensis [26] and Verrucosispora gifhornensis [27].

Micromonosporaceae strains have been isolated from diverse habitats including soil, sediments, fresh and marine water and known for their importance role as turnover of organic plant material [22]. Verrucosispora strains isolated from the marine environment were proven 
to have the ability to hydrolyze xylan [25], [26]. On the other hand, Verrucosispora gifhornensis HRI-2 that was isolated from a peat bog near Gifhorn, Lower Saxony, Germany, was not tested on xylan but was negative for cellulose decomposition [27].

TABLE I. CZI OF 15 ISOLATES IN THE PRIMARY SCREENING OF XYlanASE ACTIVITIES ON MA Plates CONTAINING 0.1\% (V/V) AZOXYLAN (BIRCHWOOD)

\begin{tabular}{|c|c|}
\hline ISOLATE ID & CLEAR ZONE INDEX \\
\hline $\mathrm{K} 1-12$ & $1.40 \pm 0.14$ \\
\hline $\mathrm{K} 1-20$ & $1.30 \pm 0.14$ \\
\hline K2-04 & $3.35 \pm 1.91$ \\
\hline K2-06 & $1.90 \pm 0.57$ \\
\hline $\mathrm{K} 2-07$ & $1.35 \pm 0.07$ \\
\hline $\mathrm{K} 2-11$ & $1.70 \pm 0.00$ \\
\hline $\mathrm{K} 2-14$ & $1.85 \pm 0.21$ \\
\hline K3-04 & $1.40 \pm 0.28$ \\
\hline $\mathrm{K} 3-10$ & $2.05 \pm 0.35$ \\
\hline $\mathrm{K} 3-13$ & $2.90 \pm 0.14$ \\
\hline $\mathrm{K} 3-18$ & $1.55 \pm 0.21$ \\
\hline K4-08 & $1.65 \pm 0.21$ \\
\hline $\mathrm{K} 4-18$ & $2.80 \pm 1.70$ \\
\hline K5-09 & $1.55 \pm 0.21$ \\
\hline K7-06 & $3.00 \pm 0.42$ \\
\hline
\end{tabular}

\section{Enzyme Assay}

K2-04 growth was described as dry weight of culture biomass with time since an attempt to obtain absorbance for OD600 was not successful because K2-04 tend to forms aggregate and precipitate in marine broth. The dry weight of K2-04 biomass increased with time towards day 12 but decline drastically at day 18 (Fig. 1). On the other hand, the highest absorbance for measurement of xylanase activity was highest at day 18. According to [28], xylanase production is correlated with growth and the maximum xylanase activity was detected at the end of exponential growth phase. The growth for K2-04 based on dry weight only displayed exponential growth pattern and the highest absorbance for measuring xylanase activity was detected right before the decline of a dry weight of the cell biomass. The highest xylanase activity of K2-04 (day 18) in marine broth was $1.836 \mathrm{U} / \mathrm{ml}$. Meanwhile, actinomycetes strain L2001 isolated from soil samples under decaying wood from China had shown $815 \mathrm{U} / \mathrm{ml}$ of xylanolytic activity under partially optimized conditions. Evidently, there are many factors that affect the yield of xylanase including a suitable inductive substrate, media, optimize fermentation conditions, temperature and $\mathrm{pH}$ [29], [30]. It is expected that xylanase activity of $\mathrm{K} 2-04$ could be higher in the optimized culture condition. The enzyme also showed stability after 20 days storage at $4^{\circ} \mathrm{C}$.

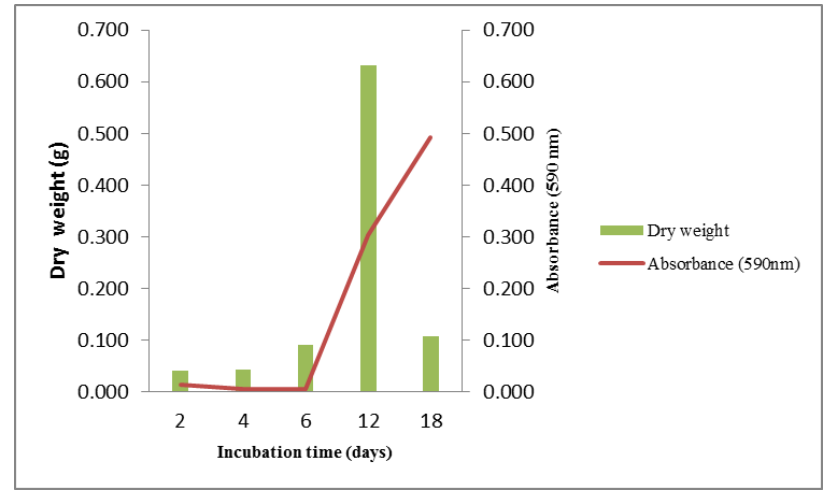

Figure 1. The dry weight of K2-04 cell biomass and xylanase enzyme activity indicated by the increase of absorbance (OD590 nm) at different incubation time

\section{CONCLUSION}

Strain K2-04, the orange pigmented actinomycete isolated from Kuantan mangrove forest sediment in Malaysia was molecularly identified as Verrucosispora sp. K2-04 While the capability of this isolate to produce xylanase is part of the important characterization of the rare Verrucosispora strain, further study of xylanase characteristic could ensure its interesting characteristic and marketability as a potential industrial enzyme.

\section{ACKNOWLEDGMENT}

The authors would like to thank the Ministry of Higher Education Malaysia for the support under grant FRGS13039-0280 and to the International Islamic University of Malaysia Research Initiative Grant Scheme (RIGS 16320-0484). Most of the experimental works were conducted with support from Kulliyyah of Science, International Islamic University Malaysia, Kuantan Campus.

\section{REFERENCES}

[1] Forestry Department Peninsular Malaysia. Forestry Statistics for the Year 2014, The Government of Malaysia, 2014.

[2] K. Jusoff and B. H. Taha, "Managing sustainable mangrove forests in peninsular Malaysia," Journal of Sustainable Development, vol. 1, pp. 88-96, Feb. 2009.

[3] K. Kathiresan and B. L. Bingham, "Biology of mangroves and mangrove ecosystems," Advances in Marine Biology, vol. 40, pp. 281-251, Dec. 2001.

[4] S. Sandilyan, "Mangrove-the evergreen emerald forest," Eco News., Dec. 2001

[5] K. Sahoo and N. K. Dhal, "Potential microbial diversity in mangrove ecosystems: A review," Indian Journal of Marine Sciences, vol. 38, pp. 249-256, June 2009.

[6] Q. Chen, Q. Zhao, J. Li, S. Jian, and H. Ren. (June 2016). Mangrove succession enriches the sediment microbial community in South China. Scientific Reports. [Online]. Available http://www.nature.com/articles/srep27468

[7] E. Kristensen, S. Bouillon, T. Dittmar, and C. Marchand, "Organic carbon dynamics in mangrove ecosystems: A review," Aquat. Bot. vol. 89, pp. 201-219, August 2008.

[8] H. Thatoi, B. C. Behera, R. R. Mishra, and S. K. Dutta, "Biodiversity and biotechnological potential of microorganisms from mangrove ecosystems: A review," Ann. Microbiol., vol. 63, pp. 1-19, March 2013. 
[9] K. Hong, A. H. Gao, Q. Y. Xie, H. G. Gao, L. Zhuang, H. P. Lin, and J. S. Ruan, "Actinomycetes for marine drug discovery isolated from mangrove soils and plants in China," Marine Drugs, vol. 7, pp. 24-44, Jan. 2009.

[10] S. V. Naikpatil and J. L. Rathod, "Selective isolation and antimicrobial activity of rare actinomycetes from mangrove sediment of Karwar," J. Ecobiotechnol., vol. 3, pp. 48-53, Nov. 2011.

[11] P. Manivasagan, J. Venkatesan, and S. Kim, "Introduction to marine Actinobacteria," in Marine Microbiology: Bioactive Compounds and Biotechnological Applications, S. Kim, Ed., Wiley-VCH Verlag GmbH \& Co. KGaA., June 2013, pp. 1-16.

[12] S. Das, P. S. Lyla, and S. A. Khan, "Marine microbial diversity and ecology: importance and future perspectives," Current Science, vol. 90, pp. 1325-1335, May 2006.

[13] R. L. Uffen, "Xylan degradation: A glimpse at microbial diversity," Journal of Industrial Microbiology and Biotechnology, vol. 19, pp. 1-6, July 1997.

[14] A. Ebringerová and H. T. Xylan, "Derivatives - Biopolymers with valuable properties, 1: Naturally occurring xylans structures, isolation procedures and properties," Macromolecular Rapid Communications, vol. 21, pp. 542-556, June 2000.

[15] M. Kamali and Z. Khodaparast, "Review on recent developments in pulp and paper mill wastewater treatment," Ecotoxicology and Environmental Safety, vol. 114, pp. 326-342, April 2015.

[16] R. Sharma, S. Chandra, A. Singh, and K. Singh, "Degradation of pulp and paper mill effluents," The IIOAB Journal, vol. 5, pp. 612, July 2014.

[17] R. Subramani and W. Aalbersberg, "Culturable rare Actinomycetes: Diversity, isolation and marine natural product discovery," Applied Microbiology and Biotechnology, vol. 97, pp. 9291-9321, Nov. 2013.

[18] P. P. Dixit and A. M. D. Xylanase, "Streptomyces hygroscopicus under solid state fermentation," International Journal of Advance Biotechnology and Research, vol. 7, pp. 38-46, Jan. 2016.

[19] S. Ninawe, M. Kapoor, and R. C. Kuhad, "Purification and characterization of extracellular xylanase from Streptomyces cyaneus SN32," Bioresource Technology, vol. 99, pp. 1252-1258. Mar. 2008.

[20] M. Sanjivkumar, T. Silambarasan, A. Palavesam, and G. Immanuel, "Biosynthesis, purification, and characterization of $\beta-1$, 4-xylanase from a novel mangrove associated actinobacterium Streptomyces olivaceus (MSU3) and its applications," Protein Expression and Purification, vol. 130, pp. 1-12, Feb. 2017.

[21] C. Florencio, S. Couri, and C. S. Farinas, "Correlation between agar plate screening and solid-state fermentation for the prediction of cellulase production by Trichoderma strains," Enzyme Research vol. 2012. p. 7, Oct. 2012.

[22] M. E. Trujillo, K. Hong, and O. Genilloud, "The family micromonosporaceae," The Prokaryotes-Actinobacteria Berlin Heidelberg, Springer-Verlag, Nov. 2014, pp. 499-569.
[23] N. A. Malek, "Bioprospecting of mangrove actinomycetes and their antimicrobials potential," Master thesis, Department of Biotechnology, International Islamic University Malaysia, Kuantan, 2016.

[24] Goodfellow, Michael, Brown, et al., "Verrucosispora fiedleri sp. nov., an actinomycete isolated from a fjord sediment which synthesizes proximicins," Antonie van Leeuwenhoek, vol. 103, pp. 493-502. Mar 2013.

[25] M. Goodfellow, J. E. M. Stach, R. Brown, A. N. V. Bonda, A. L. Jones, J. Mexson, and A. T. Bull, "Verrucosispora maris sp. nov., a novel deep-sea actinomycete isolated from a marine sedimen which produces abyssomicins," Antonie van Leeuwenhoek, vol. 101, pp. 185-193. Jan. 2012.

[26] Q. Xie, H. Lin, L. Li, R. Brown, M. Goodfellow, Z. Deng, and K. Hong, "Verrucosispora wenchangensis sp. nov, isolated from mangrove soil," Antonie van Leeuwenhoek, vol. 102, pp. 1-7, June 2012.

[27] H. Rheims, P. Schumann, M. Rohde, and E. Stackebrandt, "Verrucosispora gifhornensis gen. nov., sp. nov., a new member of the actinobacterial family Micromonosporaceae," International Journal of Systematic Bacteriology, vol. 48, ed. 4, pp. 1119-1127, Oct. 1998.

[28] A. S. Ball and A. J. McCarthy, "Production and properties of xylanases from actinomycetes," Journal of App, vol. 66, pp. 439444, May 1989

[29] S. Yuan-li, L. Xiu-ting, S. Bao-guo, L. Yue-gang, and S. Hong-xia, "Screening of actinomycetes with high producing xylanase," Advanced Materials Research, vol. 365, pp. 332-337, 2012.

[30] F. Cui and L. Zhao, "Optimization of xylanase production from penicillium $\mathrm{sp}$. WX-Z1 by a two-step statistical strategy: plackettburman and box-behnken experimental design," International Journal of Molecular Sciences, vol. 13, pp. 10630-10646, Aug 2012.

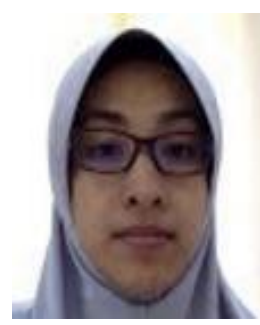

Suhaila Mohd Omar obtains her BSc in Biotechnology from the National University of Malaysia She pursues her Master of Technology (Environmental Management) in University of Malaya and obtains Ph.D. in Biotechnology from University of New South Wales, Australia. Dr. Suhaila currently held a post as Assistant Professor at Department of Biotechnology, Kulliyyah of Science, International Islamic University Malaysia. Currently, the focus of her research concentrated on bacteria from peat swamp soil, mangroves forest sediment, sponge and organic waste. While fascinated by huge microbial diversity in the environment, trained as a biotechnologist, she also interested in bioprospecting enzyme, bioactive compounds and biosurfactant from novel microbial resources. This includes both cultivation and non-cultivation approach. 